$$
\text { rief }
$$

OPEN ACCESS

Citation: F. Santiago, A.L. Goulart de Faria. (2021) Theatrical Scrawls. The Aesthetic Creations of Young Girls and Young Boys Scribble the Scene. Rief 18, 2: pp. 169-177. doi: https://doi.org/ 10.36253/rief-11396.

Copyright: (c) 2021 F. Santiago, A.L. Goulart de Faria. This is an open access, peer-reviewed article published by Firenze University Press (https://oaj.fupress. net/index.php/rief) and distributed under the terms of the Creative Commons Attribution License, which permits unrestricted use, distribution, and reproduction in any medium, provided the original author and source are credited.

Data Availability Statement: All relevant data are within the paper and its Supporting Information files.

Competing Interests: The Author(s) declare(s) no conflict of interest.
Firenze University Press

https://oaj.fupress.net/index.php/rief

\section{Theatrical Scrawls. The Aesthetic Creations of Young Girls and Young Boys Scribble the Scene}

\author{
Flávio Santiago ${ }^{1}$, Ana Lúcia Goulart de Faria ${ }^{2}$
}

Abstract

Larticolo è incentrato sulle attività teatrali per la prima infanzia, quali utili opportunità per stabilire relazioni orizzontali tra bambine, bambini, e adulti. Il contributo esplora così le potenziali soluzioni offerte dal movimento estetico delle arti nel processo di creazione di "scarabocchi teatrali" da parte dei piccolissimi. È, inoltre, evidenziato il lavoro di formazione svolto dalla Compagnia teatrale "La Baracca", insieme a educatrici e educatori dei nidi d'infanzia di Bologna. Infine, è posto in evidenza come, in questa cornice, vengano proposti approcci basati sulla fantasia attraverso le arti, plasmando così nuovi modi di essere educatrice o educatore, senza utilizzare modalità di insegnamento formali.

Parole chiave: Early Childhood Education and Care (ECEC), teatro, culture infantili, nido d'infanzia, prima infanzia.

Abstract

The paper discusses the purpose of early childhood theater, as a possibility to establish horizontal relationships between children and adults. The article thus explores the potential solutions offered by the aesthetic movement of the arts, in the creation of "theatrical scribbles" by tiny young children. In this paper, it is highlighted the training work carried out by the theater Company "La Baracca" together with Early Childhood Education and Care (ECEC) educators from Bologna, Italy. Much emphasis it is also given to how imaginative approaches through arts are proposed, thus shaping new ways of being an educator, without making use of formal teaching methods.

Keywords: Early Childhood Education and Care (ECEC), theater, peer cultures, ECEC services, early childhood.

${ }^{1}$ Professor at Federal Institute of Education, Science and Technology (IFTM) of Mato Grosso, Brasil. Researcher at the Study and Research Group on Sociology of Childhood and Early Childhood Education (GEPSI/ USP) (santiagoflavio2206@gmail.com)

2 Professor at the Faculty of Education of the Universidade Estadual de Campinas, São Paulo, Brasil. Member of Doctoral Council at the University Milano-Bicocca, Italy (2010-2018); Coordinator of the Research group "GEPEDISC - Culturas Infantis Line", and Member of Management of the "Early Childhood Forum" from São Paulo of Brasil (FPEI) in 2016-2018, and now, 2019-2021 (cripeq@unicamp.br, and ana.goulart@unimib.it). 


\section{Introduction}

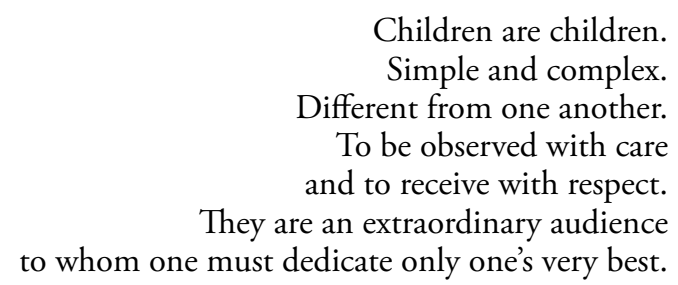

(Frabetti, 2006³ , p. 21)

The lights on the stage turn on, the tiny young girls and tiny young boys watch closely to the details of the scenario, which sometimes contains only a colored ball in the center, or a bathtub from the last century, or even a web of details impossible to observe with a single look. The actors and actresses initiate the play. The eyes of the tiny young girls and the tiny young boys become "vigilant" to the movements, which are being built on the scene, with a "guffawing silence" that rumbles throughout the theater. Aesthetic experiences are instilled, which become perceptible in the instants when the boundaries of what the play is and of whom I am - the spectator - are blurred. At that moment, the theater is taken by a set of different forms, the tiny young girls and the tiny young boys, women and men adults - actors and actresses, and non-actors and non-actresses, who merge into a single and diverse block, producing what can be called theater for the early childhood.

The art repurposes the urge of telling about self and precedes reasoning. The initial desire of communicating is pulsating. It provokes reactions, but it is a thrust. It is to make art, it is to make it "for" and "with" children, it is to provoke their artistic acts, it is not narrating the original thrust, but rather the will to drive (Frabetti, 2016, p. 20).

The show is populated by the difference of tiny young girls and tiny young boys, being open to the new: the singular act of each presentation welcomes the other, which is, at each different scene, unique and interlocutor of the play: either by the smile of a tiny young girl that draws it at the sight of a movement built by an actor, or by the guffawing silence which rumbles throughout the theater, there is an "aesthetic populating" that links the childhoods, the tiny young girls, the tiny young boys and the theater.

The little ones speak with the eyes and with their silences. The eyes that accompany the silences of children sometimes open us doors to unknown worlds. Doors that we often find it difficult to see. And we miss a thousand chances to surprise ourselves (Frabetti, 2011, p. 40).

The aesthetic expression of the theater for the early childhood trespasses the borders of the show structure - spectator, bringing up the perception of the child as a cultural and historical subject, who lives the artistic experience of the play with their whole body and their hundred languages, also producing culture as they share the artistic experience with both their peers and men and women adults.

all receptive and active senses are together, and they activate in a really human way, the human ears are capable of listening to music, the eyes are capable of contemplating the beauty, the taste which picks

${ }^{3}$ From now on, unless otherwise noted, all footnotes and translations are the Authors', Editor's Note. 
the food rather by please than by necessity of eating and surviving is a taste particularly human and there it goes, just as the faculties of thinking, of imagining which moves through the field of artistic creation, of scientific creation, etc. (Piozzi, 2005, p. 135).

The moment of the show comprises an experience, in the sense of something that allows the spectators to be launched in an adventure, in a path that affects them, that cuts out their subjectivity. And not with the idea of a scientific experiment, in which all the tiny young girls and tiny young boys go through certain similar emotional feelings and, at the end of the play, prove the theory A, B or C described by the Psychology of Development, Philosophy and Pedagogy (Leite, 2017). "A theatrical path could then be defined as a work supposed to open infinite doors "with and between" our worlds» (Frabetti, 2016, p. 19).

The experience here described corresponds to a continuous multiplicity that allows fertile cracks in the field of time and space, building instants that lead us to «stop and look, stop and listen, think slower, look slower, take time on the details, hold the opinion, hold the judgement, hold the will [...] learn about slowness, listen to others, cultivate the art of meeting, cease to speak»(Larrosa, 2002, p. 24).

Tiny young boys and tiny young girls «know how to look at the world, with those wide-open eyes, capable of marveling at it and of capturing all of its details» (Frabetti, 2016, p. 25), experiencing the world through reinterpretations of signs, gestures, and object forms, not repeating them in an exact/true way, because for «as much alike as it is, it will always be different, it will have a time fraction of difference, a joint with different angles and rotations, a more or less accentuated breath» (Frabetti, 2011, p. 45).

In the moment that one of the tiny young girls or one of the tiny young boys stands up in the middle of the show and starts reproducing movements with their body, which resemble the ones performed at the stage, they are creating, because they produce their interpretation based on what they see, feel and listen: their arms, their legs, their head, their body move from their referential standpoint, which is established by their conditions of height and experiences built along their eight months or four years of life.

These gestures, which in a first moment may strike us as being rather imperfect, compared to our "adultcentric" perception of the world, have a totality of their own, not being a fragment or an almost perfect representation of that that we adults manage to accomplish. Each movement created by the girls and boys, as they come across a scene, represents a piece of art by itself, complete and unquiet, and above all, created under the conditions of childhood that we, grown-ups, will never be able to reproduce.

William A. Corsaro (2003), atypical sociologist from the United States, carried out different researches in Italian institutions of childhood education, highlighting in his studies that girls and boys appropriate their symbolic references, being these either material or immaterial, by means of an interpretation of society, building what he calls interpretive reproduction. In this vision, the aspect of collective participation of both boys and girls stands out, for the process of symbolic interpretation is built via social relationships established with their peers and with the men and women adults.

The adjective interprets, it emphasizes the innovative aspects and the creativity of children's social participation; effectively, [...] children contribute for the creation of peer cultures, which they are a part of by drawing information from the adult world and appropriating it in order to respond to the problems of their communities. The term reproduction stresses how children do not limit themselves to just interiorize (repress) the society and culture, but they actively contribute to its production and change. That implies that children also, by means of their participation into the social world, are affected by the links in their current social structure and by the system of social reproduction. (Corsaro, 2003, p. 44). 
The thoughts of the sociologist Corsaro (2003) and the artist Frabetti (2011) share common points regarding their production of peer cultures, when these are built either from social relations or from the artistic movements raised during the course of a play, highlighting the protagonism of girls and boys, including the tiny ones.

Staccioli (2011), based on the production process of drawings made by girls and boys, highlights that at each new movement of creation girls and boys live changes connected to their experience, to knowledge, to the variation of sensibility and, although certain resemblances with the adult art may be unarguable, we must be cautious before establishing a relationship of similarity more connected to the process than to the finished representation, the final outcome.

The inventions of gestures and movements by both girls and boys, as states Caldeiron (2015), may be conceptualized as poetic insurgences of the body, constituting a communicative intentionality, which reinvents movements and senses, breaking up with the ideas of right or wrong through different languages.

The tiny young girls and tiny young boys map the world with their hundred languages, broadening dimensions regarding the knowledge of things and their repertoire of social relations, «language is not only something we have, but it is almost everything we are, which determines the form and substance not only of the world but also of ourselves, our thinking and our experience» (Larossa, 2004, p. 26).

Manoel de Barros, Brazilian poet, reveals some clues that indicate the complexity of thinking in tiny young girls and tiny young boys, as well as the ways they express themselves through "a hundred languages". He points out, still through his verses, the different symbolic arrangements that both boys and girls build in their relations with the world:

At the unbeginning it was the verb.

Only later came the verb's delusion.

The verb's delusion was at the beginning, there, where a

child says: I hear the color of the birds.

A child does not know that the verb "to hear" does not work

for colors, but for sounds.

Thus if a child changes the role of a verb, it deludes

And so.

In poetry which is the poet's voice, which is the voice of giving births -

The verb must catch a delusion.

[...]

The river that turned behind our house was the image of a soft glass

that turned behind the house.

Later on a man passed and said: Such turn the river does behind

your house is called cove.

It was no longer the image of a glass snake that turned behind

the house.

It was a cove. I find the name impoverished the image.

(2001, pp. 15-25).

The tiny young girls and tiny young boys listen to the colors of the birds and scribble the theater space, producing singular aesthetic experiences which, being either built through the guffawing silence as they observe the stories told at the stage or by their theatrical "scarabocchi", blur the limits of artistic production from adults to children, bringing to the plays the "between" element, which constitutes the possibility of new aesthetic arrangements.

Such aesthetic experiences may also be observed in other countries, and it is important to highlight that the artistic creation of the theater for the early childhood is not tied up to the language in which the play is staged, transcending the spoken language and moving amongst the audience, paraphrasing Malaguzzi (1999), by means of a hundred other languages: an eye that blinks really 
quickly, the noise from the actress' steps who moves along the stage, the arms that slide through the air building a movement that we call dance, among countless other communicative forms that place the language in a second plan at the staged performance.

\section{The Experience Brazil-Italy}

In 2014, ECEC centers' educators of the neighborhood of Bologna, in the North-Center of Italy, Elisabetta Martinelli and Maurizia Querciagrossa, presented a performance at the 19th "COLE - Reading Congress of Brazil". It is appropriate to highlight that, Ana Lucia Goulart de Faria, one of the authors of this text, attends the theater festival for early childhood in Bologna since its very first event, which in 2016 completed thirty years old, and during one of the first ones, she was able to attend to an artistic performance in a daycare center of the city accompanied by other participants in the festival, which was carried out by the educators mentioned above and, at the end of the show, Ana said to Elisabetta and Maurizia: "You are true artists, congratulations!". Without hesitating they replied: "No! We are not artists; we are daycare center educators!». These educators interpreted their artistic performance speaking Italian, when the oral word also participated, but the tiny young girls and tiny young boys "listened to them with their whole body", moving towards the aesthetic experience built at the stage. This type of performance, different from a theater play, invites the girls and boys to participate by means of an interpretative reproduction with their theatrical scrawls.

From this encounter, different aesthetic experiences have been produced, in which subjectively each tiny young girl and tiny young boy who, in relationship with their educators, participated into the performance, expressed themselves in a singular way. Some just watched it without moving, others scribbled the borders of the stage and the audience and started to build their scarabocchi teatrali, reinterpreting the movements produced by their two educators and building their own narratives.

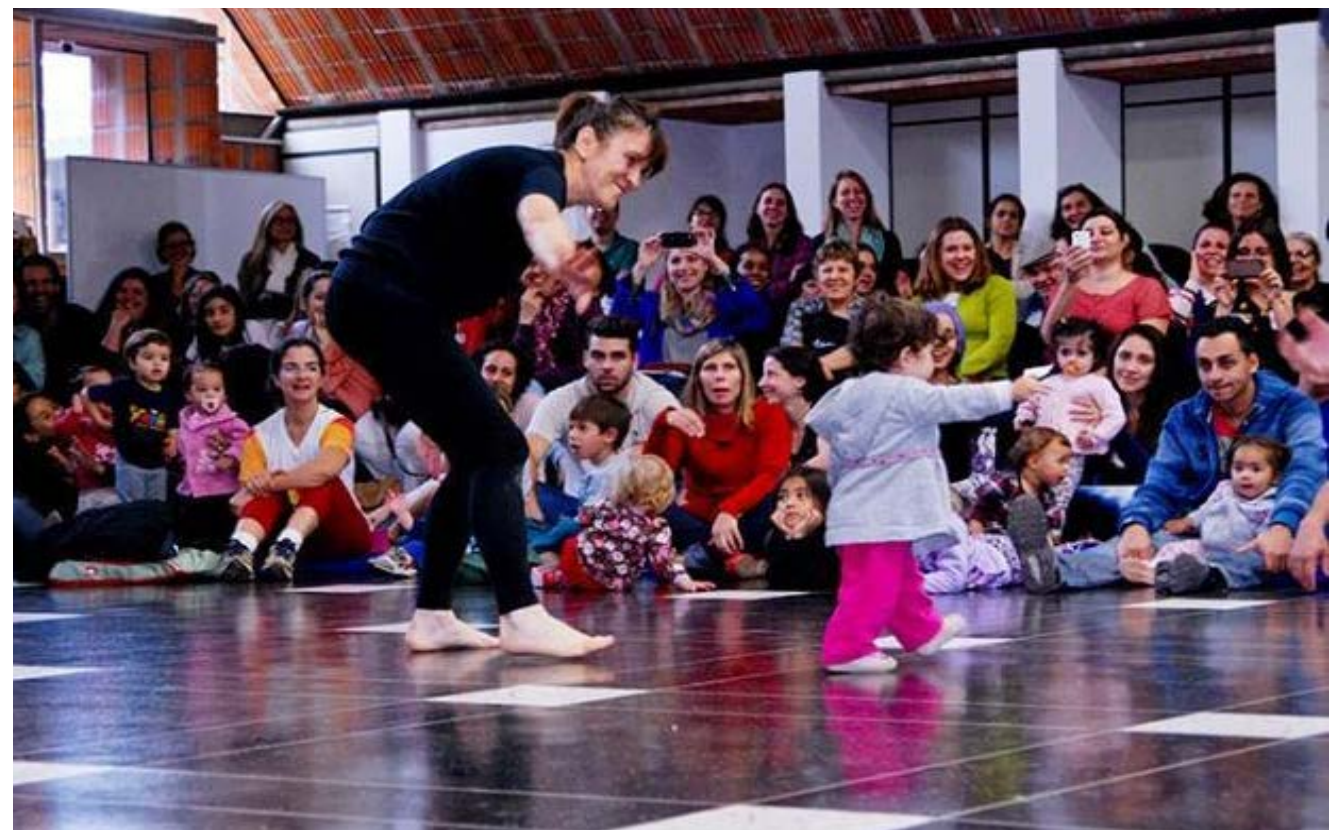

Figure 1 - Theatrical Scrawl ${ }^{4}$

\footnotetext{
${ }^{4}$ Image available at: http://www.unicamp.br/unicamp/noticias/2014/07/25/cole-traz-marina-colasanti-e-educadoras-italianas (last access: 09.01.17).
} 
The tiny young girl does not mimic: she produces her movement...Her piece! The movements built by her correspond to her aesthetic expression before the world she knows only for three or four years, and the physical possibility which her arms can perform, that corresponds to her cultural repertoire, as well as the collective ${ }^{5}$ relationship of culture production.

The production of peer cultures is neither a simple imitation nor a direct appropriation of the adult world. Children creatively appropriate the adult world in order to produce their own peer cultures. Such appropriation is creative insofar as it expands itself or elaborates the peer cultures (Corsaro, Eder, 1990, p. 200).

"Children have different ways of participating in performances» (Manferrari, Frabetti, 2006, p. 39), the silence does not mean that they are not watchful to what is happening at the stage. The different ways of participation from both girls and boys are as multiple as their languages, with possibilities so diverse that we, adult men and women, often due to an aesthetic and linguistic plastering of the adultcentric society, can neither understand nor perceive.

To do theater for young children is an experience, in my opinion, beautiful for the adults who do it [...]. I can state that, for adults - I know it for myself and for all of those who could experience it - it is an absolutely unique experience, because it forces you to make yourself available, to be continuously ready to modify yourself (Frabetti, 2011, p. 43).

The theater for the early childhood have complexity in itself, which makes it a reflective space where we are constantly disquieted to think about the protagonism of girls and boys, as well as about the different conceptions of childhoods that pervade the show. However, this reflection process, as highlights Manferrari, should not limit itself to building a:

definition neither for the children we have in front of us nor for those to whom we were going to propose. The very children who walked this path and enter the game as strong interlocutors have told us, have communicated to us, in many ways their individual paths, original and different (1996, p. 22).

The narratives built on stage are a privileged space for encounters between boys and girls, between them and the adults, providing them through those encounters with a construction of world views, of relations, of singular experiences for all subjects. Because narrating is building intimacy. As we are limited in space and time, we trust the stories to transcend the boundaries of our reality and to elaborate our experience, to recognize ourselves and to make us recognize (Manferrari, 2011). "Thus, it is not about just watching the theatrical performances, but rather the process of these children into getting to know the world and their right to watch to high quality performances, just as much as the youngsters, the adults and the elders do» (Goulart de Faria, 2014, p. 217).

\section{Conclusion and implications}

The purpose of the theater for the early childhood offers us a possibility of thinking about horizontal relationships between girls, boys and women and men adults, demanding a rupture of adultcentric postures and the opening to see with our ears, to listen with our eyes, to feel the world with our entire body, pointing out to the possibility of narrating life collectively.

\footnotetext{
${ }^{5}$ Established between other children that watch the educators who stage a narrative.
} 
The respect towards children entails adults to decentralize their perspective in order to try to understand children through their experiences, considering their realities to build educative dynamics that are relevant to the context upon which Childhood Pedagogy builds itself. This requires disposition from adults to adapt themselves, to move themselves, thus becoming an understanding subject, without limiting, however, their professional activity (Infantino, 2008)

The role of educators, as Cartacci (2017) highlights, it is create an environment to stimulate everyone's expression, interaction and disorder, and autonomy: the capacity for children to express their imagination with originality, to build their own history, through games, those expressed by symbolic actions and narratives. One cannot lose sight, during the construction of this process, of the tiny young children's participation, with their specificities in the ways they connect to the world, as it must be taken into account their different cultural belonging and their various age groups. This is a relationship based on reciprocity, in which all subjects put themselves on the spot, starting from the premise that the effects of relations produce changes and horizons in various and complex ways (Marchesi, Benedetti, Emiliani, 2013).

Putting tiny young children into focus does not mean to homogenize the idea of communication, subject and relationship, but does require an effort, a curiosity to seek understanding of different languages and ways of relating to the world, valuing each one's life story, for tiny young children are diverse and provide different questioning and needs.

As the shows begin and the lights turn on, possibilities of creation for new narratives are weaved, in which there is no adult protagonism, but instead what is posed is the opportunity for the construction of new stories in the between space: tiny young girls and tiny young boys - adults.

The theater Company "La Baracca - Teatro Testoni Ragazzi" is an international reference of a theater focused on the very early childhood, and it comes, throughout the years, by means of their plays and interlocution with girls and boys since babies, to instigate them to reflect on the potential of art on rediscovering the senses we give the world, as well as the forms and means of communication we build with children, and also to incite us to question the ways by which we silence our ears to the other 99 body languages. In addition to providing sensitive background to the educators from Bologna, who work regarding children as sensitive, qualifies the teacher's formation in daycare centers and pre-schools also "training" imagination.

During the labs, knowledge exchanges are built between artists and educators of the daycare center, taking as starting points the childhood and its singularity. The idea of construction of these labs, as Manferrari (2016) points out, comes from the awareness that it is not enough to only take children to the theater, but it is rather fundamental that educators "experience" that form of communication and enrich their expressive alphabet. From this prerogative, and inspired on the article entitled A Profession To Be Invented: The Early Childhood Educator, we can state that these moments allow one to think about «the creation of a pedagogic space for children up to three years old, and invent a new specialized teacher to work with them» (Mantovani, Perani, 2014, p. 30).

The labs are spaces where educators can risk new expressive movements with their bodies, without the load of having their gestures built in a single way. It is fundamental to highlight that there is not a correct gesture form, what is posed during these movements is the possibility of expressing by means of theater languages, with no normative judgments, and promoting the opening for the expression of each educator's artistic potential.

It is about a moment of study and research, in which are involved other forms of language, an innovative project that brings to the teacher's formation the possibility of a rediscovery of other forms of communication, as well as other ways to relate with the body and the movements produced by it, promoting the construction of new forms of perception of what it is to be a 
teacher at a daycare center, whose goal is neither to teach a class nor to teach a single way of expressing, but rather of seeing, listening and feeling the world.

Russo (2007) helps us to reflect about this form of being a teacher without teaching a class, giving an example that in the moment they tell children a story, they do not wish to achieve anything else other than have them listen, have them wish for other moments to listen: free, however with no conviction. The labs offered by the theater Company instigate teachers to build ways of being teachers without the necessity of a single language form of transmission, inviting them to transgress the lines of orality with children and to build new aesthetic encounters in the relationship with the world.

With this text, we do not intend to exhaust the discussion about the artistic potential of this form of theater offered to young children in ECEC, nor even to alleviate the countless poetic concerns it evokes. This paper is the result of reflections that also take Italian pedagogy as a theoretical basis. Among the theorists who provoke us to think about the issues mentioned here are Clara Silva, Susanna Mantovani, Enzo Catarsi, Loris Malaguzzi, Agnese Infantino, Franca Zuccoli, Gianfranco Staccioli. However, we emphasize that the ideas presented here can be characterized as an invitation to reflection between art and the education of young children and do not intend to deepen theories, but modestly intend to disseminate innovative pedagogical practices underway in Bologna in the articulation of the Secretariat of Education and Secretariat of Culture in the training of ECEC and pre-school teachers.

As part of a new show that begins, as you finish the reading of this chapter, we invite you readers of this text to read, listen and feel the words of Eduardo Galeano: "The body is not a machine as science tell us. Nor is it a sin as religion made us believe. The body is a party" (1993, p. 138).

\section{References}

Barros, de, M. (2001): O livro das ignoräças. Rio de Janeiro: Record.

Caldeiron A.C. (2015): As garatujas teatrais. Experiências e atravessamentos. Relatório de qualificação. Faculdade de Educação - UNICAMP.

Cartacci F. (2017). Osservare per ripensare il contesto relazionale. In L. Balduzzi, T. Pironi (a cura di): L'osservazione al nido: una lente a più dimensioni per educare lo sguardo. Milano: FrancoAngeli, pp. 220-239.

Corsaro W.A. (2003): Le culture dei bambini. Bologna: il Mulino.

Corsaro W.A., Eder D. (1990): Children's Peer Cultures. Annual Review of Sociology, v. 16, pp. 197-220.

Galeano E. (1993): Las palabras andantes. Tres Cantos: Siglo XXI de España Editores, S.A.

Goulart de Faria A.L. (2014): Formazione a Campinas, São Paulo del Brasile: i contributi del teatro Testoni Ragazzi Compagnia "La Baracca" di Bologna. In F. Antonacci, M. Guerra, E. Mancino: Dietro Le Quinte: pratiche e teorie nell'incontro tra educazione e teatro. Milano: FrancoAngeli, pp. 217-222.

Frabetti R. (1996): La Valigia di Alessio. In M. Manferrari, F. Marchesi, P. Vassuri, R. Frabetti (a cura di): Il Nido e il Teatro: adulto e Bambino: un rapporto da soggetto a soggeto. Bologna: Nuova Tempi Stretti, pp. 55-98.

Frabetti R. (2011, Maio-Ago): A arte na formação de professores de crianças de todas as idades: o teatro é um conto vivo. In M.A. Gobbi, S. Richter (org.): Dossiê Interlocução possível: arte e ciência na educação da pequena infância. Pro-Posiçôes, 22(2), pp. 39-50.

Frabetti R. (2016): A tutti gli invisibili del mondo Ai bambini, indivisibili tra gli invisibili. In Id. (a cura di): Pollicini ostinati: 30! Trent'anni di nido e teatro. Bologna: Pendragon, pp. 18-25.

Infantino A. (2008): Cultura dell'infanzia e servizi educativi: persistenze e innovazione. In Caggio F., Id. (a cura di): Con bambini e famiglie. Un'esplorazione in luoghi d'infanzia. Bergamo: Junior Edizioni, pp. 171-199. 
Larrosa J (2002, Jan/Fev/Mar/Abr): Notas sobre a experiência e o saber de experiência. Revista Brasileira da Educação, n. 19, pp. 20-28.

Larrosa J. (2004): Linguagem e educação depois de Babel. Belo Horizonte: Autêntica.

Leite Donizetti Pereira C. (2017): O que pode a imagem? Experiências imagéticas com crianças e professoras (disponível em: < https://www.youtube.com/watch?v=cojvOJWmEIY >; acesso em: 13.01.17).

Manferrari M. (1996): Dal paese di neve in vento. In Id., F. Marchesi, P. Vassuri, R. Frabetti, (a cura di): Il nido e il teatro. Adulto e bambino: un rapporto da soggetto a soggetto. Bologna: Nuova Tempi Stretti, pp. 19-48.

Manferrari M. (2011, Maio/Ago): Histórias são naus que cruzam fronteiras. In M.A. Gobbi, S. Richter (org.): Dossiê Interlocuçâoo possível: arte e ciência na educação da pequena infância. Pro-Posiçōes, 22(2), pp. 51-62.

Malaguzzi L. (1999): Histórias ideias e filosofia básica. In C. Edwards, L. Gandini, G. Froman: As cem linguagens da criança. Porto Alegre: Artes Médica, pp. 12-24.

Mantovani S., Montoli Perani R. (2014): Uma profissão a ser inventada: o educador da primeira infância. In A.L. Goulart de Faria, A.Vita (org.): Ler com bebês: contribuiçôes das pesquisas de Susanna Mantovani. Campinas: Autores Associados, pp. 61-78.

Marchesi F., Benedetti S., Emiliani F. (2013): L'asilo nido: um serviço per la prima infanzia. In F. Emiliani (a cura di): Il bambino nella vita quotidiana: psicologia sociale della prima infanzia. Roma: Carocci ${ }^{8}$, pp. 133-156.

Piozzi P. (2015, Jan.): Marx, o operário, e as leis da beleza. Mouro-Revista Marxista, a. 6, n. 9, pp. 132-143.

Russo D. (2007): De como ser professor sem dar aula na escola da infância. In Goulart de Faria S. Amaral Mello (org.): Territórios da Infâncias: Linguagens, tempos e relaçôes para uma pedagogia para a criança pequena. Araraquara: Junqueira\& Marin, pp. 57-83.

Staccioli G. (2011): As di-versōes visíveis das imagens infantis. In M.A. Gobbi, S. Richter (org.): Dossiê Interlocução possível: arte e ciência na educação da pequena infância. Pro-Posiçōes, 22(2), pp. 21-37. 
